College of William \& Mary Law School William \& Mary Law School Scholarship Repository

1989

\title{
Closing the Circle of Constitutional Review from Griswold v. Connecticut to Roe v. Wade: An Outline of a Decision Merely Overruling Roe
}

William W. Van Alstyne

William \& Mary Law School

\section{Repository Citation}

Van Alstyne, William W., "Closing the Circle of Constitutional Review from Griswold v. Connecticut to Roe v. Wade: An Outline of a Decision Merely Overruling Roe" (1989). Faculty Publications. 746.

https://scholarship.law.wm.edu/facpubs/746 


\title{
CLOSING THE CIRCLE OF CONSTITUTIONAL REVIEW FROM GRISWOLD $V$. CONNECTICUT TO ROE V. WADE: AN OUTLINE OF A DECISION MERELY OVERRULING ROE ${ }^{1}$
}

\author{
WILLIAM VAN ALSTYNE*
}

Griswold v. Connecticut ${ }^{2}$ held that no state may make pregnancy a state-imposed risk of sexual intimacy within marriage. To the extent that there are medically safe means of minimizing pregnancy risks two people who are married to each other do not want to incur as an incident of their inarital sexually intimacy, Griswold held that the state may not forbid them to take such precautions to minimize those risks as they think appropriate. That a married person might attempt to use a birth-control device in relations with someone other than his or her spouse is doubtless true, $^{3}$ but even so, the Court held, this observation does not justify a state

* Perkins Professor of Law, Duke University.

1. Prompted by Dellinger \& Sperling, Abortion and The Supreme Court: The Retreat from Roe v. Wade, 138 U. PA. L. REv. 81 (1989). This excellent article faults the Supreme Court's plurality opinions' shortcomings in Webster v. Reproductive Health Services, 109 S. Ct. 3040 (1989). (See also the strong follow-on article by Estrich and Sullivan, Abortion Politics: Writing for an Audience of One, $138 \mathrm{U}$. PA. L. REV. 119 (1989)). It also provides a strong, reinforcing account of Roe v. Wade. This brief essay is meant to respond to key portions of that article, to see whether they can be satisfactorily answered. I am not sure they can be, and, privately, I would like to think they cannot be, but I think the effort to try may be worthwhile anyway, perhaps just as a compliment to Dellinger and Sperling, if nothing else. The principal challenge addressed here is the authors' challenge that they frame from Griswold v. Connecticut, 381 U.S. 479 (1965). They put the question in this way (Dellinger \& Sperling, supra, at 93): "If Griswold is to remain good law, how can one fail to conclude that women have at least a presumptive fundamental liberty interest in deciding to terminate a pregnancy?" One possible answer is this: Griswold speaks to a fundamental liberty interest of marital intimacy generally free of state scrutiny. The "terminate a pregnancy" claim, on the other hand, is a considerable stretch insofar as it implicitly also asserts a claim of right to kill third party life. Deriving a fundamental right to do the latter, even as an incident of the former (i.e., as an incident of marital intimacy), much less as a free-standing individual right, is the burden that Roe, and not Griswold, must sustain. In the terms Justice Blackmun provided in Roe v. Wade, it is doubtful that Roe carries that burden at all convincingly or well. From Webster v. Reproductive Health Services, it now appears that at least four (perhaps five) members of the Supreme Court agree. It is not obvious that they are wrong.

2. 381 U. S. 479 (1965).

3. The interest the state relied upon in justification was this express concern. See 381 U.S. at 505 (White, J., concurring); Brief of Appellee at 15-17; Oral Argnment of Appellee, at 1-5, reprinted in P. Kurland \& G. Casper (eds.), 61 Landmark Briefs and Arguments of the Supreme Court of The UNITEd States: Constrtutional Law 165, 179-81, 430-34 (1975). The Connecticut statute, virtually the last of its kind in any jurisdiction, dated from the turu-of-the-century 
law that on that account also makes medically safe means of birth control altogether unavailable to persons acting mutually within marriage. The state, the Court agreed, may do much to discourage adultery, but not by means that also prejudice the decisions of married persons acting mutually withm marriage. ${ }^{4}$

The Griswold decision was explicitly rooted in rights of marital privacy. 5 It reinforced the civil hberty of married persons to be free from searches and seizures conducted in their bedrooms, to be free from criminal inquisitions into the details of their mutual expressions of intimacy, and to be exclusive to one another on terms of intimacy they, rather than some umit of government, deeined best. It proceeded from a long series of prior cases similarly reviewing state restrictions on marital freedom

moralist movement headed by Anthony Comstock. It was a measure designed to discourage illicit sex-regarded, generally, as sex outside of marriage. The state made no claim that the statute was adopted owing to some alleged state interest in promoting population-there was no evidence of any such interest in the origin of the statute; moreover, it is doubtful on due process grounds that such a statist view would be upheld in the Supreme Court.

4. The tendency of state laws to encroach on protected relationships in the course of coping with some felt problem otherwise within legislative authority is a familiar phenomenon for thc Supreme Court. It is commonly dealt with just as it was in the Griswold case. See, e.g., Butler v. Michigan, 352 U.S. 380 (1957) (state statute banning films unsuitable for minors held invalid insofar as, in accomplishing that aim, the statute also eliminated such films for adults).

5. The emphasis on marital privacy is explicit in Justice Douglas's opinion for the Court (the emphasis on marital privacy is made four times in his opinion, the first in italics), similarly explicit in the concurring opinion by Justice Goldberg ("marital privacy"), writing separately for himself, Chief Justice Warren, and Justice Brennan, and explicit still again in the concurring opinion by Justice Harlan as well. The decision was foreshadowed by Justice Harlan's compelling opinion in Poe v. Ullman, 367 U.S. 497, 522 (1961) (Harlan, J., dissenting).

It is one thing when the State exerts its power either to forbid extra-marital sexuality altogether, or to say who may marry, but it is quite another when, having acknowledged a marriage and the intimacies inherent in it, it undertakcs to regulate by means of the criminal law the details of that intimacy.

[The] intrusion of the whole machinery of the criminal law into the very heart of marital privacy, requiring husband and wife to render account before a criminal tribunal of their uses of that intimacy, is surely a very different thing indeed from punishing those who establish intimacies which the law has always forbidden and which can have no claim to social protection.

Id. at 553 .

And Griswold is free and clear of Eisenstadt v. Baird, 405 U.S. 438 (1972)-i.e., the latter is not at all enclosed by, or implied by, anything in Griswold itself. Eisenstadt, whether as a substantivc due process case or as an equal protection case, may stand or fall on some separate notion of a right of fornication-i.e., a "Griswold"-type right possessed by persons not married, not entering that status of relationship, exclusivity, mutual legal obligation, etc., but nonetheless intensely desiring sexual intercourse (and claiming a right of access to contraceptive devices toward that end). Justice Brennan begged the crucial question in treating Eisenstadt as an equal protection result arising from Griswold. Nothing logically required their equivalence at all. The difficulty with Eisenstadt is that it appeals to an equal protection claim that is simply question-begging and, at the same time, serves as a bootstrap. The decision remains wholly unexplained to this day. (The most recent, clear statement on both Griswold and Eisenstadt is Sandel, Moral Argument and Liberal Toleration: Abortion and Homosexuality, 77 CALIF. L. REV. 521, 526-28 (1989)). Cf. D. RichaRds, Foundations of AMERICAN CONSTITUTIONALISM 212-47 (1989). 
and marital privacy, and it has been succeeded by other decisions strongly linked with the same consistent theme. ${ }^{6}$

Fully in keeping with Griswold, risks incidental to acts of intimacy within marriage are for the married couple to appraise. It is for them to decide how to act or not act in respect to those risks, with altogether such degree of care and precaution as both or as either may think best, without any hindrance by the state. Prior to the Court's decision in Roe v. Wade, in 1972, however, no one had supposed that even marriage would also entitle one to destroy third-party life that one's own actsalbeit acts of marital intimacy - had brought about. ${ }^{7}$ Deriving such a claim, even as an incident of marriage, much less as a generalized free standing constitutional right unrelated to marriage, obviously raises a far different issue than any previously resolved.

This very different kind of claim was involved in Roe v. Wade. It was not confined to a claim of abortion within marriage, moreover, but extended far more generally-indeed even unqualifiedly-to a woman's right to kill the gestating life within her solely according to her own choice, with any willing physician's professional help. ${ }^{8}$ It was claimed, moreover, as a "fundamental" right, fully equal to the status sheltering acts of intimacy within marriage itself, and allegedly specially protected by the Constitution virtually according to the same standards that would protect freedom of speech.

6. For earlier cases, see references and citations in Griswold itself, 381 U.S. at 482-86. For related subsequent cases, see, e.g., Michael H. v. Gerald D., 109 S. Ct. 2333 (1989); Zablocki v. Redhail, 434 U.S. 374 (1978); Moore v. City of East Cleveland, 431 U.S. 494 (1977); Wisconsin v. Yoder, 406 U.S. 205 (1972); Boddie v. Conuecticut, 401 U.S. 371 (1971); Loving v. Virginia, 388 U.S. 1 (1967). $C f$. the rather different description of Griswold recently given in R. BoRK, THE TEMPTING OF AMERICA 95-100 (1990).

7. Cf. the very different locutiou adopted by Dellinger \& Sperling, supra note 1, at 93, 94, 9697. The authors characterize the issue in Roe as the question of "government impos[ed] mandatory childbearing," "government compulsion to bear a child," "state-compelled childbirth," and "mandatory childbearing," collapsing the controversy into a strong image of an obviously repellant sort. The image sought is, surely, that of government orchestrating and mandating child-bearing iu the service of the state; we are moved to see here a totalitarian statist scheme. If one accepts the authors' description, one is at once properly disturbed-i.e., we are encouraged to think this is but some fragment of Nazi Germany or Stalinist Soviet Union directing families to have children against their will for the good of the state. Is this any part of what is at issue iu Roe, however, or is what is at stake there something quite different altogether-that acts of sexual intimacy even in a free society are not regarded as utterly socially inconsequential, that autonomy and freedom are not unbounded, and that freedom to do as one likes is only a half-truth, qualified by some responsibility for what may ensue; and that fetuses in gestation, resulting from one's uninterfered with liberty, are not regarded as excrescences to be sloughed off (or, in the same easy locution, "terminated"), that there is, after all, no general right to kill, and that one must answer to that principle, too?

8. See also Planned Parenthood v. Danforth, 428 U.S. 52 (1976) (further confirming lack of tie to marital privacy foundation for Roe-state law meant to protect husband's shared interest in determining the fate of fetus conceived within marriage held invalid, Blackmuu's opinion relying entirely on $R o e$ ). 
To be sure, it-i.e., the claim of right-was described not as a right to destroy third-party life, but rather as a right to "terminate an unwanted pregnancy." The description can gain no constitutional purchase on that account.9 In no respect did it change the nature of the crucial distmction the Court was required to address between Griswold v. Connecticut and Roe v. Wade, given the difference between an anti-abortion law and an anti-contraceptive law, as the state insisted that there was.

In Roe v. Wade, the key question was whether the Constitution provided a right to destroy third-party life in gestation. Justice Blackmun began his address to that question for the Court in Roe in exactly the right way. He quite rightly observed when, as in the circumstances of Roe, it is clear that some kind of third-party human life was clearly present, such that a claim of right to kill and destroy was necessarily implicated in what some physician was asked to do on request, it was not for this Court to attempt to substitute its view respecting the significance of that life for any nonarbitrary view that more democratically representative branches of government than itself might hold. ${ }^{10}$ Nothing in the fourteenth amendment or in article III of the Constitution so empowers the Court. Unless, then, the view reflected in a law respecting the sufficiency of third-party life worthy of protection from death by willful abortion could be dismissed as so extreme as to verge on the irrational, or to be a mere disguise for prejudice of some determinable kind, then it-and not the feelings of members of the Court (as to how they might differently measure the calculus of fetal life)-must generally control. ${ }^{11}$

Yet, there is now no blinking away the fact that despite that clear and well stated position for the Court, Justice Blackmun ended by doing exactly that which the Court disclaimed. Indeed, he had the Court declare that no legislatively-recorded consensus on the subject would be regarded by the Court as acceptable unless the consensus it reported selected as the earliest date of worthiness of general protection from death by abortion a fetus which, since conception, had been allowed to live and

9. It would not advance a useful discussion of the issue, for instance, to pose a claim of hypothetical right to put to death an unwanted and burdensome child, or an unwanted and burdensome neighbor or relative, by putting it in terms of "terminating" an "unwanted" relationship of either sort.

10. Roe v. Wade, 410 U.S. at 159 ("We need not resolve the difficult question of when life begins. When those trained in the respective disciplines of medicine, philosophy, and theology are unable to arrive at any consensus, the judiciary ... is not in a position to speculate as to the answer.") (emphasis added).

11. The alternative, if neither the Court nor any legislative body may presume to judge, would leave it wholly to each pregnant person unilaterally to decide-a position making them judge and jury in a case involving the death penalty for third party life contingent solely upon one's ability to make contact with a physician willing to carry it out. But what basis is there in the Constitution to anchor such a claim? Roe v. Wade furnishes none. 
develop through the twenty-fourth week of its life. ${ }^{12}$ This Court thus declined to accept any view that a claim of a right to kill a dependent human being was seriously-rather than not seriously-implicated by abortion at any earlier date despite the clearest expression of belief by a state legislature to the contrary. It thereby substituted judicial hubris for judicial deference, substituting its view of the (un)importance of life for the fetus as against the view reported in state law. It ousted any different view than its own, thus doing precisely what it disclaimed was appropriate for any court.

Virtually no state took the view of the matter this Court took at the time of Roe v. Wade. ${ }^{13}$ Nor, of course, had Congress presumed to override any state's determmation of that critical question. Nor is there anything in Roe to show why these state legislative determinations should be overridden on a matter the Court conceded was entirely subject to good faith debate, just as it then was and just as the Court itself recognized. ${ }^{14}$ It is little wonder, then, that the decision has been difficult to "explain," as it is even now unexplainable. The inexplicable nature of the raw "holding" of Roe has simply become increasingly obvious as the issue has recurred in the Court, challenged here obliquely, as it assuredly has been term after term. ${ }^{15}$

It was obvious to at least four Justices just last term, moreover, in Webster v. Reproductive Health Services. ${ }^{16}$ Indeed, it accounts for the basic turn that was there made in repudiating Roe. The weakness of Roe hes in its determination that no claim of "right" to kill third-party life becomes seriously (i.e., critically) involved as such until a fetus in gestation is so far developed that it inight even survive if plucked from its womb, though only the Court (or rather some members of the Court) may think this to be so and others, including concerned legislative bodies, may see it as present when the act that kills occurs a great deal earlier than that.

Nor is it fair criticism of the plurality opinion in Webster as failing to state the basis for its conclusion that the abortion decision is not-as

12. That is, Roe $v$. Wade embraces a unilateral right of feticide up to the time of ex utero fetal viability, pegged by the Court at or even later than the 24th week of gestation, months after the physiology of the fetus is complete. Yet, curiously indeed, No state whatever had taken so light a view of the matter (with the arguable then-recent exception of New York) as the line Justice Blackmun asserted in Roe to be constitutionally required.

13. See supra text accompanying note 10.

14. See supra note 10.

15. See the appropriate comment by Ely, The Wages of Crying Wolf: A Comment on Roe v. Wade, 82 HARV. L. REv. 920, 947 (1973) ("[Roe v. Wade] is bad because it is bad constitutional law, or rather because is is not constitutional law and gives almost no sense of an obligation to try to be.").

16. 109 S. Ct. 3040 (1989). 
was the right in Griswold - a "fundamental" hiberty interest simply because that opinion put its emphasis on the state's interest in protecting fetal life instead of on the absence of a right to kill. ${ }^{17}$ To be sure, in terms of the conventional strict-scrutiny, bifurcated style of judicial review, ${ }^{18}$ the criticism may seem well taken; but we suggest that it is not, because the point was itself iniphcit. However one might tentatively be inclined to define a "right" as a right or not as a right (or indeed as "fundamental" or as "not fundainental"), not the least relevant part of so deciding is, obviously, the giving of soine degree of forethought to what the characterization means. If, therefore, the claimed right is one that, as to be defined, would include the right to destroy a fetus by chemical death or surgical shicing and dismemberment, it may well be reasonable to consider just that very fact in the course of deciding whether to characterize any such prerogative as a "fundamental" right after all.

In short, we suggest, one must first consider what it is that the claim of "fundamental" right will be said to extend to, and then pause so to see whether it nakes any sense. Better, then, to measure the conscionability of the claimed "right" in the first place by attending to its consequences, than later on try to explain just how one managed to describe it in such protean terms.

This is, noreover, not at all a small inatter. It is not a small matter because "winning" the argument at step one (i.e., succeeding in claiming the high ground of "fundamental" right in "terminating a pregnancy") clearly prejudices the opposing case in a subtle way at step two. Step two, the state's "compelling interest" burden, is already prejudiced if at step one, it has already been stipulated that the woman's unilateral right to "terminate her pregnancy" (which is also a right to annihilate the fetus, for such is part-and-parcel of anything that amounts to "terminating" the pregnancy) is a "fundamental" right as such. It is, therefore, quite logical to put the emphasis on the fact that feticide is involved (the alleged step-two, state interest part of the inquiry) first, after all, so to show the more clearly how the step one claim (of "fundamental" right) cannot itself be maintained in so gross a form precisely because of what it presumes to embrace. Nothing in Roe even comes close to show that it does. Unless, then, stare decisis somehow commands the entrenchment

17. Cf. Dellinger \& Sperling, supra note 1 , at $83-84,93-97$ (faulting the plurality opinion for this alleged failure).

18. According to the convention of so-called strict scrutiny review, one first determines whether the claimed right is specially favored (e.g., first amendment freedom of speech) or not specially favored (e.g., ordinary freedom of commercial exchange), and then determines whether, in light of that determination, the state has met or not met the burden differentially required of it under the circumstances. 
of even obvious constitutional error, itself contested from the beginning less than two decades ago, ${ }^{19}$ Roe cannot now be sustained.

Griswold, then, did not imply Roe, or anything even close. ${ }^{20}$ And, of course, neither did any of its strong, traditionally-rooted antecedent cases, such as Myers v. Nebraska, ${ }^{21}$ or Skinner v. Oklahoma, ${ }^{22}$ nor related subsequent cases, such as Moore v. City of East Cleveland. ${ }^{23}$ But more striking still, Justice Blackmun's own reasoning in Roe was-as already noted-in contradiction to the Court's actual holding in the case. What Justice Blackmun said for the Court in Roe actually provides the strongest sort of argument, without change, to overrule the particular

19. Compare Plessy v. Ferguson, 163 U.S. 537 (1896), with Brown v. Board of Education, 347 U.S. 483 (1954) (After a half century of reiteration of Plessy by the Supreme Court, during which its basic doctrine went essentially unquestioned and was, moreover, widely relied upon in literally thousands of state government decisions, Plessy overruled). Compare Erie Railroad v. Tompkins, 304 U.S. 64 (1938) with Swift v. Tyson, 41 U.S. (16 Pet.) 1 (1842), (repudiating on constitutional grounds a general federal common law applicable in diversity cases, overruling a century-old case on the same point).

The Supreme Court ought not be defensive in respect to its clrallenged decisions. Stare decisis is least compelling in instances of constitutional adjudication, see, e.g., United States v. Scott, 437 U.S. 82, 101 (1978); Burnet v. Coronado Oil \& Gas Co., 285 U.S.. 393, 406-08 (1932) (Brandeis, J., dissenting), as evidenced by this Court's more than 130 past overrulings of its own decisions, barring some special circumstance not shown to be present here. See also Monaghan, Stare Decisis and Constitutional Adjudication, 88 Colum. L. REv. 723 (1988). The author of Roe joined in an opinion by Justice Brennan just two terms ago going out of its way to provide an advisory opinion overruling a constitutional decision of this Court nearly 100 years old and not at all necessary to confront on the facts of the case. South Carolina v. Baker, 485 U.S.. 505 (1988) (overruling Pollock v. Farmers' Loan \& Trust Co., 157 U.S. 429 (1985)). (Cf. the concurring and dissenting opinions, 485 U.S. at 527-34.) So, too, it was Justice Blackmun who concurred in this Court's decision in National League of Cities v. Usery, 426 U.S. 833 (1976), only to change his mind and become solely responsible for overruling its constitutional holding within ten years. Garcia v. San Antonio Metro. Transit Auth., 469 U.S. 528 (1985). Even more than was true of this Court's decision in the National League of Cities case, Roe $v$. Wade has, from the beginning, produced questions very much directed to its soundness as such, and not merely to some technical or marginal uncertainty. While certain decisions of this Court may claim some measure of repose from the extent to which, for instance, the nation's monetary system has become fixed in reliance on those decisions, sucl that a constitutional crisis might ensue were they now to be disturbed (e.g., the Legal Tender Cases (Knox v. Lee), 79 U.St 457 (1871), overruling Hepburn v. Griswold, 75 U.S.. 603 (1869)), there is no similar explanation to be ventured here to excuse the Court.

20. Indeed, the right confirmed in Griswold would be less significant (less "fundamental"?) if, though the state forbade voluntary means of contraception (and were constitutionally privileged to do so), there would nonetheless remain a later-in-time right to induce an abortion, to kill the gestating embryo or fetus, and to have it removed or disposed of at any time within 24 weeks so long only as the woman's own health remained unimpaired (which is the alleged "fundamental" right Roe embraced). It is the absence of any free wheeling claim of the latter sort that, in some measure, strengthens the very strong Griswold claim.

2l. 272 U.S. 52 (1926).

22. 315 U.S. 535 (1942).

23. 431 U.S. 494 (1977). 
decision therein made. Roe $v$. Wade was an aberration of judicial legislation, not unlike others the Court has previously been willing to correct. ${ }^{24}$

If all this is sound, moreover, one can make no headway against the constitutionality of an otherwise valid law restricting the circumstances of lawful abortion on ground that its enforcement is necessarily problematic in apphication with respect to those who may seek its evasion by taking recourse to the different policies of some other state. ${ }^{25}$ So much is already true even under Roe itself-i.e., states already differ even within the scope of that decision, and such differences doubtless do count for something. It is not to be seriously suggested in this setting more than other settings, however, that a particular law is unconstitutional on that account. If it were, then federalism itself would be pretty much unconstitutional as well.

So, im the abortion setting, to be sure, some persons equally subject to any such law may, indeed, seek its evasion. Yet, it is also clear that they liave no "right" thus to proceed, and they do not thereby gain some constitutional immumity by the means they have pursued. In Williams $v$. North Carolina, ${ }^{26}$ for instance, the Court agreed that the State of North Carolina could validly prosecute a person for bigamy when, without in fact actually meaning to give up his residency in North Carolina, a North Carolina resident went to Nevada, stayed there long enough to secure a "divorce" from lis Nortlı Carolina wife, married another person who was fully aware of the circumstances, and then promptly moved back to Nortll Carolina with his new wife. The Supreme Court agreed that that person remamed subject to North Carolina's bigamy law and that the state could decline to give full faith and credit to the Nevada divorce decree by proving, in the course of the bigamy prosecution, that the defendant did not in fact mean to take up real residency in Nevada and give up real residency in Nortll Carolina. There is no reason to believe the result would be different, in a cognate abortion case. ${ }^{27}$

24. See supra note 19 (examples and discussion).

25. We address this point and several others, infra, because it has been thought by some to be appropriate to consider as an alternative or supplementary basis for the decision in Roe. See, e.g., Dellinger \& Sperling, supra note 1, at 108.

26. 325 U.S. 226 (1945).

27. Constitutionally speaking, the case is not different than were a parent bound by a given state's anti-child-abuse criminal statute to seek evasion of the law by removing the child to a neighboring state just temporarily (i.e., without effecting an actual change of residency), therein to mistreat the child in a manner disallowed by the criminal law of his or her state of residence, though not disallowed by the criminal law of the state to which he or she took the child briefly for the very purpose of inflicting the mistreatment there. That the state law of the state of actual residence might not apply as a matter of fact might be true; but that the state could provide that its law would apply in such circumstances is also true, and certainly nothing in the Constitution would hold it amiss. 
So it is not true as a matter of law that some persons would be exempt from the state anti-abortion law imsofar as they have the practical knowledge, ways, and means of travelling outside the state to have an abortion performed. It is rather a matter-as in any such case as embezzlement, extortion, gambling, and the like--that the extent to which such evasions may remam undetected or unprosecuted goes to show the limit the state of residence reaches as a practical matter without a surveillance system both too expensive and too intrusive to be felt worthwhile to pursue. Assuredly one's realization of this limitation generates no "right" to kill or a "right" to enlist a willing physician-for-fee to help in the killing within the state. One cannot generate a constitutional right of abortion in this way. ${ }^{28}$ Rather, the prerogative of states to strike different attitudes and a different balance on the subject of abortion, as on many others, all within limits framed by the fourteenth amendment, is just what is meant by federalism. ${ }^{29}$

Nor is it useful to seek to uphold Roe on the different ground of an alleged prejudice against women or a manifestation of discrimination by inen. To the contrary, if the matter were thought relevant, these laws, insofar as they do not dismiss abortion as of little consequence-i.e., as of little or as of no social concern-may in some measure falsify the stereotype of what men are thought to be like. ${ }^{30}$ It is equally incorrect to suggest that the regulation of abortion "affect[s] only women."31 Quite the opposite is true. ${ }^{32}$ The controversiality of appropriate constraints affect-

28. See also supra note 27. Of course, evidence of a pattern of selective enforcement would raise a separate and serious question. See, e.g., Yick Wo v. Hopkins, 118 U.S. 356, 373-74 (1886).

29. See, e.g., New State Ice Co. v. Liebmann, 285 U.S. 262, 311 (1932) (Brandeis, J. dissenting).

30. To suppose that men (who do still predominate in state legislatures) generally would favor less permissive abortion laws than women runs counter to the usual (i.e., dismissive) view of menthe view that sees men as more likely than women to favor laws favoring promiscuous sex. (Presumably, promiscuous men would favor permissive-rather than strict-abortion laws, since more permissive abortion laws permit lower-risk promiscuous sex insofar as they provide a new choice to abort the chance offspring, assuming only the woman can be persuaded to agree. The nominal option of abortion, to the extent permitted by law, may create its own pressure to assert it. There is no reason to think that men have no role in influencing its course.) See also H. Rodman, R. SARVIS, \& I. BONAR, THE ABORTION QUESTION 141 (1987) ("On the whole, from the early 1960's to the mid-1980's, national polls have reported that slightly higher percentages of men than women express favorable attitudes to abortion."). Cf. Olsen, Unraveling Compromise, 103 HARV. L. REV. $105,117-26$.

31. Cf. Dellinger \& Sperling, supra note 1, at 105 ("There is an additional basis to expect searching judicial scrutiny for abortion regulations: not only do these regulations implicate a fundamental right, they also affect only women.").

32. It would be remarkable to suggest that a married man has no shared interest with his wife, for instance, in deciding to abort an unexpected pregnancy the two together strongly feel they cannot afford, and the unwanted maturation and birth of which must profoundly affect their circumstances, as they themselves understand those circumstances best. See also supra note 30 and accompanying text. 
ing this subject, noreover, is even now extremely wide and strongly engaged. It cuts reinarkably across distinctions of sex, race, or class, as it did also prior to 1972. The departure inade in Roe cannot now successfully be explained away in any such terms as these..$^{33}$

Although the assertion that inost conceptions may "spontaneously abort"- to inove now to still a different point ${ }^{34}$-nay well be true, it is neither here nor there for purposes of ineasuring the validity or applicability of an anti-abortion law. The distinction is the obvious one that there is no willful and affirmative act undertaken here by the married couple, the woman, or any doctor ineant to kill. Whether a spontaneous abortion be seen as but part of "nature's way" or soinething else, it stands on a different footing, or so reasonable people may surely believe. The Griswold calculus itself may fairly be deemed to enclose the "pregnancy-reducing-risk" incidence of ordinary spontaneous abortions (i.e., those that occur without active pro-killing efforts by the pregnant person or another hired to bring it about). On principle, it is hard to see how it makes any real headway against the standard, anti-abortion case.

It is true-to advance to yet another point-that even in the mere defense of certain kinds of special property (e.g., one's home) or a good faith (albeit mistaken) belief of serious peril to oneself or to another, perfectly unexceptionable examples of excused homicides are a feature of standard criminal law. No doubt sone of these excused homicides are theinselves compelled, even on constitutional grounds, while others, though not similarly compelled, are well open to legislatures so to provide. Neither suggests a cynicism in the law. That there nnay be a coinparable calculus within any particular abortion law is by the same token not necessarily a sign of contradiction or of inconsistency. It may be, rather, a reflection of similarly resolved conflict and thought. ${ }^{35}$ That a law acknowledges a zone-soinetimes a generous zone-of excused conduct does not on that account make the law that does so either cynical or

33. Nor can the constitutional resolution of any particular abortion regulation properly be made to turn on the relationship of the substance or content of the regulation to the gender characteristics of a given legislature, rather than on a consideration of what the particular regulation provides. To proceed in that fashion would require the Court to sustain a state statute identical in every particular to a statute also adopted by the legislature in the adjoining state while nonetheless presuming to hold unconstitutional the adjoining state's indistinguishable statute. Nothing in the Constitution authorizes the court so to decide constitutional questions-i.c., differently from state to statc. Cf. Carolene Products Co. v. United States, 304 U.S. 244, 252 n.4 (1938).

34. Cf. Dellinger \& Sperling, supra note 1, at 106 ("States have never protected the potential life of all fertilized ova. Sixty-two percent of fertilized ova spontaneously and naturally abort, a figure that dwarfs the number of induced abortions.").

35. See M. Glennon, Abortion and Divorce in Western LAW 25-31 (1987) (discussing West German Constitutional Court decision in this setting). 
inconsistent, but rather may make it more rational and more responsive to the complexity of human events. ${ }^{36}$ And so it may be here as well.

The range of such excused conduct, to be sure, was a restricted range in some jurisdictions, as we know, a substantially wider range in others (and prior to Roe an unlimited range in none). Nor is it to be thought peculiar that this was so or that, within himits, it might be so still again. ${ }^{37}$ Where, for instance, the conception is still barely that and not significantly more advanced into gestation, in inany jurisdictions there may well be no felt illogic or inconsistency with a standard abortion restriction still to permit abortion although one would not permit the procedure but for a circumstance which the case actually fits.

The exainple of violence and of rape may well illustrate just such a circumstance. It is not irrational or inconsistent here to permit an early excused abortion-or so at least reasonable persons inay assuredly believe. There is hittle here that resembles the Griswold framework froin which we have worked these things out. Indeed, this kind of claim in itself may have a constitutional basis of its own, though it is unnecessary now so to decide. ${ }^{38}$ This is not a case where two persons engaged in intercourse, free to take all precautions either or both deemed suitable. The risk of conception was not a risk privately weighed, but rather a risk aggressively and violently miposed. Accordingly a legislative provision to permit the option of seeking termination of possible conception, despite destruction of the still-minuscule, gestating embryo, is not cynical or inconsistent, but understandable and rational. ${ }^{39}$ A similar idea doubtless explains excuse insofar as the pregnant person's life would be imperiled by carrying the gestating einbryo to full term, though by hypothesis the explanation is not the lack of voluntarisin in the conception, but rather something else. Even so, failure to provide excuse in these circuinstances, too, would be the anomaly surely and, indeed, might itself rise to

36. Cf. Dellinger \& Sperling, supra note 1, at 108 ("Most abortion laws also contained an exception for cases where continuing the pregnancy threatened a woman's health. ... The fact that no state consistently acted upon its professed interest in protecting all fetal life suggests either that the interest was something less than compelling, or that there was a different interest altogether.").

37. There is, one may suggest, moreover, no fundamental anomaly under federalism in respect to what different states may permit or not permit vis-a-vis excused abortions, all within a limited range, as was true prior to Roe. To the contrary, such differences are a reflection that legislative bodies are by no means of a single mind.

38. Including (albeit not limited to) concerns addressed in the thirteenth amendment prohibition on involuntary servitude. See Thompson, $A$ Defense of Abortion, 1 PhIL. \& Pub. Affairs 47 (1971) and compare Tushnet, The Supreme Court on Abortion, in ABORTION, MEDICINE, AND THE LAw 161, 170 (J. Butler \& D. Walbert eds. 1986).

39. Indeed, nothing in the mere overruling of Roe suggests per se that a legislature would be forbidden to leave first trimester abortions entirely alone, or also to permit abortion for exceptional circumstances beyond that time, insofar as the balance of fairly considered policies at stake were manifest in the law. Overruling Roe does not direct what legislatures are to do. 
the level of constitutional complaint. That possibility likewise is wholly reserved here without, however, affecting the general case.

What is decided here, however, is itself not unimportant. To the contrary, rather, it sets the basic terms of subsequent debate, and it is that which was strongly implied last Term. There is no such thing as a personal, free-standing, fundamental right embedded in the Constitution of the United States to kill gestating life. Roe v. Wade, in suggesting otherwise, ${ }^{40}$ proceeded on an assertion not derived or derivable from Griswold v. Connecticut, from any previous case, or indeed, from any constitutional clause. It was rather judicial legislation, and it is now overruled. Laws affecting abortion are not exempt from judicial review, as we have taken care to note. They are, nonetheless, to be worked out principally within the political process rather than in the courts. There is nothing reinarkable that this should be so now, as it was even less than two decades ago. Not the least task the Court perforins is to express no reservation about the political processes of this country when the Constitution itself expresses none.

40. Indeed, in holding otherwise and much more-that there is such a right to kill even through the 20th, or 24th or 28th week, with any willing physician's professional assistance toward that end, and just for such reason as is satisfactory to the parties participating in the acts, whatever or whoever else may be involved, with only the woman's health being an admissible concern for the state. (This, in brief, was the scope of Roe's breathtaking claim.) 